\title{
Karier Subkultural dan Kritisisme Street Artist Yogyakarta
}

\author{
Jagad Hidayat Jati, Derajad S. Widhyharto \\ Departemen Sosiologi, FISIPOL UGM \\ jagad.jati@mail.ugm.ac.id | derajad@ugm.ac.id
}

\begin{abstract}
This article is based on research in 2017 about street artists in Yogyakarta. The study uses qualitative method with following issue and visuals approach on six street artists to extract 3 aspects: issue, medium, and actor. Street artist as subcultural career is a process of creating space and efforts to maintain it. Street artists is mentally affected through perception of surroundings, then their awareness of reality and hopes for public spaces collide so that alternative spaces are created in the street walls, in the end the walls become space wich symbolically interpreted by the viewer. To be able to create space and maintain it, street artists have a side of criticism. Starting from the awareness of differences in public space, selection of street as a core element in the city, as well as accuracy in momentum. Criticism is carried out repeatedly and build a resistance identity. Each street artist is in a position to oppose and criticize the various problems that surround them through two work patterns, issue first or place first. The pattern is also carried out together to form a collective identity.
\end{abstract}

KEYWORDS Youth | Subcultural Career | Street Artist | Space Creation | Criticism

\section{PENDAHULUAN}

Sesuai dengan julukannya sebagai kota seni dan budaya, Yogyakarta juga menawarkan berbagai peluang karier yang berhubungan dengan karya-karya seni budaya. Mulai dari sebagai seniman yang memajang karya seninya di dalam ruang atau menampilkannya di panggung, hingga sebagai seniman yang bergerak bebas di jalanan. Lukisan besar berwujud mural, huruf-huruf indah graffiti, atau sekadar coretan tagging tak sulit ditemukan di sekitar ruang publik Yogyakarta. Para pembuat yang kerap disebut street artist tersebut datang dari kalangan pemuda yang merasa berhak menggunakan jalanan dengan bebas sebagai media berekspresi sebagaimana para pemilik kepentingan seperti pemerintah atau perusahaan yang menghias ruang publik dengan spanduk dan baliho besar bermuatan pesan-pesan instansi atau iklan suatu produk. Jiwa pemuda para street artist diikuti oleh kekritisan mereka terhadap isu-isu dan mas- alah sosial politik yang ada di masyarakat sekitar. Misalnya saja saat era panasnya referendum keistimewaan Yogyakarta, banyak street artist menyuarakan tema "Jogja Istimewa". Lalu akhir-akhir lalu ketika pembangunan hotel marak, muncul karya berslogan "Jogja Ora Didol" (Jogja Tidak Dijual) serta "Jogja sold out". Belum lagi masalah pemerintah dan carut marut politik Indonesia yang menjadi sorotan. Karya lainnya misalnya bertajuk "Butuh Badut Lucu? Hubungi Senayan”, "Jangan Percaya Politisi”, "Usut Tuntas Kasus Munir", dan tema-tema kritis lain pun kemudian bermunculan (Jati 2017).

Keberanian street artist untuk menyerobot masuk ke ruang publik ini sesuai dengan semangat subkultur, yang mana subkultur terbentuk sebagaibudaya tandingan atas budaya yang telah mapan dalam wujud gerakan, tindakan, kegiatan, kelakuan kolektif, atau budaya bagian dari budaya besar. Perlawanan yang erat diusung subkultur bisa be- 
rupa apa saja seperti agama, negara, institusi, musik, gaya hidup, dan segala yang dianggap umum (Barker 2003:374-409). Menjadi seorang street artist di Yogyakarta berarti menjalani karier subkultural sebagai seniman yang tidak termasuk dalam budaya tradisional serta punya jarak tersendiri dengan keeklusifan seni kontemporer yang terpajang dalam sekat-sekat ruang pameran. Street artist ditakdirkan untuk akrab dengan lingkungan sekitar dan erat dengan ilegalitas (Young 2014:1). Mereka memamerkan langsung karyanya pada media yang paling dekat dengan masyarakat. Media-media di jalanan ini tentu saja adalah milik pihak yang memiliki otoritas, namun tanpa sebuah izin khusus mereka bersaing dengan para pemilik kepentingan. Semua dilakukan demi menyuarakan kekritisan lewat visual bermakna sehingga pemirsanya bisa terpengaruhi pikirannya, menciptakan gerakan, maupun memantik kebijakan. Artikel ini ingin mengupas rumusan masalah yang terdiri dari bagaimana proses perjalanan karier subkultural street artist di Yogyakarta dan bagaimana bentuk kritisisme yang menjadi bagian dari identitas street artist itu sendiri.

Secara historis kehadiran street artist sejak awal sudah erat dengan konteks politik yang mempengaruhi dan dipengaruhi. Dalam buku karya Barry (2008) dikatakan bahwa di awal kemerdekaan Indonesia tahun 1945 telah tercipta ruang alternatif pada tembok-tembok masyarakat. Ruang tersebut tercipta lewat praktik penandaan berupa gambar dan tulisan penyemangat perjuangan rakyat. Hal yang sama terjadi tahun 1998 saat reformasi, suara-suara pelengseran presiden lantang di teriakkan lewat tembok pula (Barry 2008). Selain dari konteks politik, pengaruh yang membuat seseorang terjun ke jalanan sebagai street artist juga datang dari ruang spasial dimana dia berada. Seperti banyaknya sekolah-sekolah seni dan masifnya pengaruh pengetahuan dari Universitas-universitas di Yogyakarta. Kemudian tidak sulit menemukan sanggar, galeri seni, pertunjukan, juga tokoh-tokoh budaya. Ditambah pula peran-peran komunitaskolektif yang banyak memicu gerakan (Hadi 2014). Kondisi-kondisi ini mendukung terlahirnya karier subkultur sebagai street artist, apalagi kemudian di Yogyakarta isuisu sosial politik sering tergaung secara dinamis.
Para street artist akan menempatkan karya seninya tak jauh dari topik yang sesuai dengan isu tersebut dan tidak jarang karyanya menjadi instrumen tindakan politik (Fitri 2015). Misalnya saja saat masyarakat Yogyakarta merasa resah dengan masifnya pembangunan hotel yang akan mengancam ketersediaan air warga sekitar, street artist dengan kritisnya mampu mengkomunikasikan ide-ide serta mengekspresikan kekecewaan masyarakat terhadap pemerintah ataupun pihak swasta lewat karyakarya bertajuk "Jogja Asat" atau Jogja kekeringan.

Street artist tak bisa lepas dari konteks politik dan keruangan. Karier subkultural tersebut muncul dari pengalaman seseorang pada ruang yang mendukung untuk terjadinya perlawanan. Apa yang masih belum jelas adalah bagaimana tiap-tiap pelaku pada awalnya bisa memulai turun ke jalan dan mengambil keputusan untuk memilih street artist sebagai karier. Memilih street artist sebagai karier subkultural juga berarti bahwa mereka harus bertahan hidup dengan karier tersebut. Padahal yang ada di mata masyarakat awam adalah menggambar atau menulis-nulis di tembok tidak bisa menghasilkan pendapatan, yang ada malah keluar uang untuk modal membeli peralatan. Di sisi lain menjalani karier tersebut juga terancam oleh hukum karena akrab dengan ilegalitas. Tulisan ini ingin melengkapi hal tersebut lewat paparan proses perjalanan karier subkultural street artist di Yogyakarta dan bagaimana rupa kritisisme yang menjadi bagian dari identitas street artist itu sendiri.

\section{KERANGKA TEORITIK}

Artikel ini menggunakan beberapa landasan, di antaranya adalah teori ruang publik milik Lefebvre (1991), teori identitas dari Castells (1997), dan kritisisme dalam standar Agger (2008). Media yang digunakan street artist untuk berkarier adalah ruang publik, dari sanalah mereka membangun identitasnya yang erat dengan kritisisme untuk bertahan dari dulu sampai sekarang.Ruang publik menjadi elemen yang sangat penting di negara demokrasi. Di sana setiap anggota negara bisa berdiskusi secara terbuka mengemukakan suaranya dan mengartikulasikan kebutuhannya sebagaimana prinsip demo- 
krasi berdiri (Little John \& Foss 2009). Di sisi lain, masyarakat bisa melakukan diskusi yang rasional, membentuk opini mereka, serta menjalankan pengawasan terhadap pemerintah. Namun pada kenyataannya geliat atau aktivitas-aktivitas tersebut belum sepenuhnya berjalan mulus di Yogyakarta. Ruang-ruang banyak yang diokupasi oleh pihak-pihak tertentu yang berkuasa. Hal ini sesuai dengan konteks ruang bagi Lefebvre (1991:26-27) yang mana ruang adalah sebuah produk yang diproduksi sebagai sarana pemikiran dan tindakan dengan upaya kontrol serta dominasi seperti dalam relasi produksi Marx. Karena itu di setiap ruang akan selalu ada usaha untuk melanggengkan kekuasaan dan dominasi. Orang-orang yang berebut tadi masing-masing melakukan produksi ruang sosial. Produksi ruang sosial terjadi ketika para street artist secara mentalitas terpengaruhi oleh kondisi ruang spasial yang menghasilkan nilai-nilai. Nilai tersebut dimaknai secara individual maupun secara kolektif, terjadilah kemudian sebuah tindakan sosial.

Fenomena yang terjadi di Yogyakarta lebih jelas dapat dilihat melalui pandangan Lefebvre (1991) yang melihat public space sedang berada dalam perebutan. Pendekatan ruang dari Lefebvre (1991) cocok dengan karier subkultural street artist yang memanfaatkan jalanan Yogyakarta sebagai ruang alternatif untuk berkarya. Mereka memproduksi ruang alternatif untuk merebut dominasi pihak yang berkuasa dan untuk mewujudkan aktivitas dan geliat yang seharusnya ada sehingga terjadi di alog demokratis.

Produksi ruang yang dilakukan street artist didasari oleh sebuah landasan pemikiran kritisisme. Penentuan standar kekritisan yang ada dalam identitas ini merujuk pada argumentasi Ben Agger. Menurutnya, yang membuat 'kritis' ada dalam hal pembukaan kedok aspek dominasi, baik secara material maupun kultural. Mereka yang kritis tidak akan ikut dalam narasi besar membekukan dominasi ke dalam pola hukum abadi karena telah membuka matanya untuk melihat sesuatu dari sisi lain bukan hanya refleksi atas dunia statis yang terlihat saja. Kritisisme menuntut pemikiran mendalam untuk melihat hal dibaliknya berupa konstruksi-konstruksi dinamis yang tidak bebas nilai. Sehingga dengan kritisisme kita bisa mengungkap struktur masyarakat untuk memahami akar dan alasan rasional suatu permasalahan (Agger 2008:343).

Tahap penciptaan ruang dengan kritisisme secara terus menerus bisa membangun identitas mereka. Castells (1997) mengungkapkan konstruksi identitas terbuat dari nilai dan pengetahuan yang selalu berada dalam konteks yang ditandai dengan relasi kekuasaan. Setidaknya ada tiga bentuk dan asal bangunan identitas yaitu Legitimizing Identity, Resistance Identity, dan Project Identity. Posisi street artist sebagai suatu karier subkultur bisa men erjemahkan bentuk bangunan identitas yang mereka punya yaitu Resistance Identity. Pada bentuk ini identitas dihasilkan oleh aktor-aktor yang berada dalam kondisi terdevaluasi dan terstigmatisasi oleh logika dominasi. Sehingga terbangun benteng pertahanan dalam prinsip bentuk identitas yang berbeda, yaitu dorongan untuk melawan (Castells 1997:7). Para street artist berada pada kondisi terdevaluasi karena pengaruh dominasi yang besar para pemilik kapital. Identitas mereka kemudian dibangun atas dasar mempertahankan nilai-nilai demokratis. Tahap lanjutan setelah individu terkonstruksikan identitasnya, masing-masing dari mereka yang merasakan kesamaan dasar akan membentuk identitas kolektif.

\section{METODE PENELITIAN}

Penelitian ini dilaksanakan dalam kerangka kualitatif dengan pendekatan following issue dan visual methodology. Teknik pemilihan informan dilakukan dengan menggunakan tipe purposeful yakni peneliti memilih individu-individu dan tempat untuk diteliti karena mereka dapat secara spesifik memberi pemahaman tentang problem riset dan fenomena dalam penelitian tersebut (Creswell 2015:217). Keenam street artist adalah orangorang yang telah menetap di Yogyakarta dan terkenal karier subkulturnya karena karya seninya yang kritis telah lama malang melintang menghiasi dinding-dinding di Yogyakarta. Mereka adalah Ismu yang mayoritas karyanya berupa mural, Here-Here dengan karya mural dan graffiti, Methodos dengan karya mural, Media-Legal dengan street art berupa 
stensil, serta Anagard dan Guerillas dengan karya stensil juga. Informan dipilih dengan 2 kategori yaitu street artist yang banyak berbasis dengan karya mural atau lukisan tangan dan street artist yang berbasis stensil atau melukis menggunakan alat bantu cetakan. Kategori ini dipilih dari banyaknya kategori street art karena dari keduanya biasanya yang paling vokal dalam menyampaikan pesan tertentu.

Jenis sumber data digunakan terdiri dari data primer dan sekunder. Data primer didapat dari pengamatan lewat following atau mengikuti street artist selaku aktor pada kegiatan sehari-harinya untuk menggali data mengenai 3 aspek yaitu medium, isu, dan aktor itu sendiri. Kemudian dilakukan in-depth interview dengan street artist sebagai informan. Sedangkan data sekunder yang digunakan dalam penelitian ini berupa media foto dokumentasi visual karya-karya keenam street artist, buku-buku, dokumen, artikel, surat kabar, dan internet. Data tersebut dianalisa lewat alur merangkum, memilih hal-hal pokok dan penting, menentukan fokus, dan menemukan pola. Validasi data didapat dari triangulasi yang dilakukan dari tiap-tiap penemuan.

\section{KAUM MUDA DAN KARIER SUBKUL- TURAL STREET ARTIST}

Berbicara mengenai karier sebagai street artist tak bisa lepas dari sejarah awalnya di kota-kota dataran utara benua Amerika seperti New York, Los Angeles, dan San Fransisco. Ketiganya disebut-sebut menjadi tempat lahirnya standar street art modern. Kata modern disini berafiliasi pada teknik-teknik seni baru dan kompleks yang digunakan untuk merespon ruang publik masyarakat kontemporer (Schacter 2013:98). Ekspresi street art modern paling awal dapat kita rasakan pada tahun 1970-an dimana graffiti-graffiti atau street art berbentuk tulisan-tulisan menghiasi sisi kereta hingga lorong-lorong subway. Kaum muda pada kala itu menggunakan teknik menulis yang cukup memperhatikan nilai estetik seni. Muncul beberapa teknik modern dengan bermedium cat aerosol/spray can seperti wildstyle, 3D, bubble, dan sebagainya. Era 70-80an bisa menjadi titik loncat yang signi- fikan dalam sejarah street art karena anak muda kala itu dengan kesadaran individunya membuat gerakan berkesenian secara bebas untuk merespon lingkungan sosio-politik. Dengan tangan sendiri mereka terjun dalam 'battle of meaning' lewat ekspresi artistik (Gastman \& Neelon 2011). Ekspresi artistik bernafas modern pada ruang publik tak hanya terjadi pada streetart berwujud graffiti namun juga mural yang ber-bentuk lukisan dinding dan seni dengan media lain. Beberapa memang benar-benar dibuat dengan teknik baru berkat kemajuan teknologi seperti stiker, poster wheatpaste, stensil atau cap karton, dan seni instalasi. Tak hanya berkutat pada eksistensi nama, muatan pesan yang dibawa dalam street art kian bertambah rumit dan akrab dengan bahasan subkultur underground lain seperti semangat perjuangan kelas dari skena musik musik punk dan hip-hop (Gray 2015). Kemajuan media komunikasi dan teknologi memantik penyebaran street art dengan cepat ke seluruh penjuru dunia dengan cita rasa karya yang sesuai dengan isu di masing-masing kota di wilayah berbeda, para street artist mengangkat tema dan isu yang spesifik mengenai tempat mereka berada (Young 2014:80).

Masuknya street art modern dari negara barat ke Yogyakarta dibawa oleh kaum muda. Mereka terpengaruh musik, majalah, dan tontonan populer yang memuat rupa street art, misalnya seperti VCD kehidupan seniman jalanan Jean Michael Basquiat yang merebak sekitar tahun 2000-an. Pola graffiti yang digoreskan secara sembunyi-sembunyi di tengah kota ala Basquiat diadopsi oleh kaum muda dengan bergerilya berbekal cat spray. Teknik spray and running tengah malam ini kemudian lazim disebut sebagai bombing. Pelaku graffiti menyasar titik-titik strategis dalam kota mulai dari dinding, rolling door toko, papan jalan, dan lain-lain. Musik hip-hop juga membawa pengaruh signifikan dalam masuknya street art di Yogyakarta. Musik yang erat dengan dunia underground kala itu membawa serta budaya jalanan lain seperti breakdance, MC (Master of Ceremony), dan tentu saja street art terutama graffiti (Barry 2008:12). Dari banyaknya pelaku street art di Yogyakarta ada yang hanya 'iseng-iseng doang', terbawa tren, dan ada juga yang serius berkarier di dunia street art. Mereka yang memilih berkarier 
menjadi street artist berarti menjalani hidup dengan bertumpu pada karya-karya street art. Secara konsisten mereka berkarya dari dulu hingga kini di jalanan. Semangat perlawanan dari street art juga dipegang guna menyematkan pesan sosial, kritik politik, dan nilai-nilai bermakna lainnya pada karya-karyanya. Beberapa nama di Yogyakarta yang terkenal memenuhi kriteria tersebut dalam berkarier subkultural adalah Ismu, Here-Here, Methodos, Media-Legal, Anagard, dan Guerillas.

Sebelum memilih berkarier subkultural sebagai street artist keenam tokoh tadi memiliki latar belakang yang hampir sama yaitu akrab dengan dunia seni dan pergaulan dinamis kaum muda. Mereka mempunyai kedekatan dengan ruang spasial dimana mereka tinggal yaitu ruang-ruang publik di Yogyakarta. Ismu sebagai seseorang yang sejak awal sudah bercengkrama dengan kemunculan street art modern di Yogyakarta adalah contoh nyata street artist yang datang dari latar belakang seni. Street artist yang menghabiskan masa kecilnya tinggal dekat pasar dan terminal bus di Wonosari tersebut sejak SD sudah mulai suka menggambar. Dari tetangganya, Ismu mengenal cat dan kuas sebagai media berkreasi karena saat SMP kelas 2 sampai SMA kelas 2 dirinya diajak bekerja membantu tetangganya untuk mengecat bus dan truk. Dari sana kecintaan pada dunia seni dan keahlian mengolah warna, garis, hingga membuat tulisan terasah. Ismu masuk kuliah di Pendidikan Seni Rupa UNY tahun 2000, tak lama berselang setelah itu Ismu terlibat pada berbagai komunitas seni baik di kampus maupun di jalanan seperti komunitas Apotik Komik yang pada tahun 2002 melakukan gerakan kolektif untuk menghiasi tembok-tembok Kota Yogyakarta dengan karya street art. Sama dengan Ismu, street artist kedua yaitu Here-Here sejak awal sudah berinteraksi dengan dunia seni. Pemuda yang menghabiskan masa kecil dan remajanya di daerah Kemetiran Kidul Yogyakarta ini tertarik dengan seni lukis ketika kelas 3 SMP dirinya melihat sekelompok orang yang menggambar mural di tembok jalanan dekat rumahnya.Kemudian di SMSR (Sekolah Menengah Seni Rupa) Here-Here bertemu dengan orang-orang yang suka dengan street art seperti MUCK dan LoveHateLove yang keduanya merupa- kan orang yang menyuburkan generasi awal street art jenis graffiti era 2000-an berbasis di Wijilan. Berbeda dengan Ismu dan Here-Here, Methodos adalah inisial dari street artist yang tidak mengenyam pendidikan formal seni di sekolahan. Meskipun begitu Methodos sudah menyukai menggambar sejak dirinya masih SD karena terpengaruh temannya yangpintar menggambar dan ayahnya yang jeli dalam hal seni busana atau fashion. Methodos saat remaja kerap menyempatkan diri datang ke pameran-pameran seni rupa yang tak sulit ditemukan di ruang-ruang sekitar Yogyakarta. Secara pemikiran Methodos juga terpengaruhi dari lingkungan sekitarnya yang fanatik agama sehingga dirinya memberontak dan sering dimasukkan sebagai isu dalam karyanya.

Lingkungan sekitar juga mempengaruhi Media-Legal yag saat remaja banyak berhubungan dengan komunitas punk. Lagu-lagu berbau perlawanan, protes, dan hal-hal politis menjadi santapannya sembari berdiskusi bersama temantemannya tentang isu-isu terkini dari zine atau rilisan tulisan independen lokal. Di sisi lain Media-Legal juga sejak kecil sangat mengagumi seni rupa dari kegiatan membaca komik dan menonton kartun. Media-Legal sendiri terpancing untuk mambuat street art berteknik stensil setelah menonton film dokumenter tentang demonstrasi anti perang di Seattle tahun 1968 yang banyak menggunakan mural stensil sebagai medium menyuarakan suara di jalanan. Street artist di Yogyakarta yang juga memakai teknik stensil dan sama-sama suka membawa isu-isu tertentu dalam karyanya adalah Anagard serta Guerillas. Anagard adalah orang yang datang dari latar keilmuan seni. Dulu dia lulus dari SMSR Padang dan kemudian menetap di Yogyakarta sejak tahun 2004 untuk menuntut ilmu di Jurusan Seni Patung ISI. Pada masa kuliah hingga sesaat setelah lulus di tahun 2010, Anagard banyak berkecimpung pada dunia 'seni tinggi' yang biasa kita lihat di ruang-ruang galeri atau pameran. Tak berapa lama kemudian dia merasakan tidak puas karena membuat karya bermakna sosial di ruang tertutup sehingga tidak semua orang bisa melihat.Kebosanan yang memuncak di tahun 2011 mengantarkannya untuk pertama kali membuat karya di jalan dengan mem-bawa isu-isu permasalahan pemerintah saat itu yang di- 
dapat dari diskusi-diskusi dengan sesama mahasiswa saat kuliah. Tokoh keenam yaitu Guerillas di awal tahun 2001 berpindah dari Temanggung dan menetap ke Yogyakarta untuk menuntut ilmu di MSD (Modern School of Design) jurusan Desain Grafis. Jurusan tersebut dirasa sangat sesuai dengan minatnya karena sejak masa sekolah dirinya sudah banyak membuat goresan-goresan gambar di buku-buku pelajarannya karena terpengaruh komik hingga majalah-majalah bertema BMX dan Skateboard. Di dalam majalah semacam itu banyak visual-visual arena-arena BMX dan Skate yang dipenuhi coretan-coretan street art. Terlebih dirinya tertarik dengan karya-karya visual dari Banksy, seniman street art ternama bergaya stensil dari Inggris. Sekitar tahun 2004 dirinya bertemu temanteman dengan satu ketertarikan, beberapa dari mereka adalah orang-orang yang menjadi tokoh di balik berdirinya sebuah toko seni urban 'Jokja Apparel' dan komunitas seni 'Survive!Garage'. Bersama orang-orang tersebut Wimbo bergerak di jalan membuat stensil-stensil kecil yang direplikasi di berbagai tempat.

\section{MENGIPTAKAN KARYA DENGAN CIRI KHAS}

Apa yang membedakan orang-orang yang menjadikan street artist sebagai karier subkultural dengan orang-orang yang hanya coba-coba atau bersifat eventual adalah konsistensi. Dari awal berkarya sampai sekarang street artists tetap membuat karya. Di dalam konsistensi tersebut ada perjalanan pengolahan gaya atau ciri khas. Misalnya sebelum membuat karya yang dominan gambar, Ismu pertama kali membuat karya dari berbasis teks saja. Dia menulis di tembok kata-kata 'hamba nominal', 'dosa visual', atau kata-kata plesetan dari kalimat yang sudah terkenal lebih dulu seperti saat booming telepon genggam untuk pertama kalinya Ismu membuat kata 'gairah poliponik'. Saat tuntutan dunia kampus mengenalkan Ismu dengan kuas dan cat, Ismu kemudian mencoba memakai gambar lukisan atau mural di tembok. Kekhasan karya Ismu berada pada kemampuannya dalam merespon ruang dengan cepat dengan pemilihan isu yang tepat, ekspresif dengan komposisi visual yang ramai, dan detil gambar kecil-kecil melengkapi sorotan gambar utama. Beralih ke Here-Here yang bisa disebut sebagai street artist yang paling eksploratif, berbagai teknik telah dia lakukan seperti teknik wheatpaste atau menempelkan gambar-gambar besar, melakoni graffiti dengan gaya tagging atau menandai tempat, hingga membuat mural dengan karakter khasnya yang berupa kepala bulat bergigi tajam. Karakternya selalu dibuat tematik dengan isu yang dibawa, misalnya karakternya bisa berseragam polisi saat mengomentari isu lalu-lintas atau karakternya duduk di meja besar menyerupai pemangku kuasa. Kesederhanaan figurnya menaikkan tingkat rekognisinya di mata masyarakat dan bisa lebih menguatkan isu yang dibawa. Methodos juga pernah menggunakan teknik wheatpaste seperti Here-Here di awal kemunculan sebelum akhirnya fokus menggunaan kuas dan cat. Gaya gambarnya terinspirasi dari beberapa street artist dunia. Seruan dan kritik sosial dari 'Obey' serta 'McGee' dibumbui gaya bernuansa horor dan sadismenya 'Neckface' adalah rahasia ramuannya. Figur-figur absurd dan teks yang provokatif sengaja dipilih agar pemirsanya lebih mencerna makna dan ikut berpikir. Pada perkembangannya di tahun 2016 gambar-gambarnya mulai halus dalam artian unsur horornya berkurang. Garis-garis penuh cipratan, sudut-sudut tajam, dan objek seram mulai berganti dengan goresan rapi dan friendly terhadap mata pemirsa. Menurutnya penghalusan yang terjadi menjawab tantangan bagaimana caranya agar karyanya bisa lebih diterima oleh masyarakat luas di ruang publik.

Ketiga karya pada gambar 1 sama-sama mengomentari isu yang santer terdengar di Yogyakarta pada tahun 2016-2017. Karya Ismu (kiri) dan Here-Here (tengah) mengkritisi kebijakan pembangunan yang berlebihan di Yogyakarta sedangkan karya Methodos (kanan) menyentil ketakutan masyarakat terhadap orang asing. Ismu menampilkan gambar masyarakat yang hierarkis seperti piala dimana yang paling tinggi adalah raja, dijunjung oleh bawahannya, dan paling bawah adalah rakyat. Ada gambar sebuah sumur yang tidak ada airnya sedangkan di bawah ada rakyat yang meminta. Ismu ingin menyoroti pembangunan hotel yang dibi- 
arkan menguras ketersediaan air warga di sekitar. Konteks keruangan juga diperhatikan oleh Ismu karena karya bergambar piala tersebut diletakkan di jalan timur hotel Melia Purosani yang notabene adalah komplek toko-toko pembuatan piala. HereHere pun juga memperhatikan keruangannya, dia meletakkan karyanya di depan stasiun tugu seakan-akan menyambut tamu yang datang ke Yogyakarta dengan figur konglomerat yang sedang menyusun gedung-gedung tinggi. Methodos meletakkan karyanya di daerah Prawirotaman yang mana daerah tersebut sehari-harinya banyak dikunjungi turis luar negeri yang bercengkrama dengan warga lokal. Rasa takut terhadap orang asing atau disebut xenophobia disindirnya dalam tulisan 'xenophobia is adorable diseasé.

Beralih pada street artist yang berbasis pada stensil yaitu Media-Legal, Anagard, dan Guerillas, mereka bertiga mempunyai ciri khas pada karya yang terbuat dari cetakan gambar yang disemprot spray ke tembok. Pada awalnya Media-Legal membuat cetakan dengan kertas ukuran A3 yang dipotong sesuai pola gambar. Kepraktisan metode stensil membuat karyanya cepat dalam pengerjaan dan dapat direplikasi di banyak tempat seperti box listrik, tembok toko, tiang jalan layang, dan sebagainya. Awalnya gaya karya stensil Media-Legal hanya berupa gambar saja yang secara simbolis mengandung makna untuk diterjemahkan sendiri pemirsanya. Pada perkembangannya Media-Legal membubuhi stensilnya dengan imbuhan kata-kata yang berkaitan dengan ruang atau isu yang dibawa. Sehati dengan Media-Legal, Anagard mengakui bahwa stensil praktis dan cepat pengerjaannya sehingga mengurangi resiko ketahuan, mengingat bahwa saat membuat karya dirinya tidak berizin. Gaya stensil awal Anagard juga cukup sederhana yaitu hanya berwarna hitam dan putih tanpa banyak kombinasi gambar-gambar rumit. Baru pada tahun 2014 dirinya lebih memperhatikan kualitas karyanya dengan menambah paduan warna dan pola-pola grafis berbeda. Anagard banyak mengambil pola grafis dari seni nusantara seperti wayang, batik, hingga pola floral tumbuhan-tumbuhan lokal. Pada figur human-oid, Anagard tak jarang juga mengambil kepala-kepala binatang yang menyimbolkan sifat manusia. Aksen artistik yang diutamakan tak meniadakan pesan sosial yang dia bawa. Anagard masih menyuarakan pesan-pesan seperti perdamaian, saling mencintai sesama, dan kritik perilaku masyarakat modern. Tak seperti Anagard dan Media-Legal yang memodifikasi stensilnya dengan penambahan detail sehingga terlihat halus seperti mural manual, karya Gurillas sampai sekarang masih kental dengan cetakan mentah sebuah stensil. Bahasa-bahasa visual yang satir dan mengejek dengan cara cerdas ala Banksy juga Guerillas anut. Karakter karya Guerillas selalu berpijak pada unsur satir dan humor. Satirnya

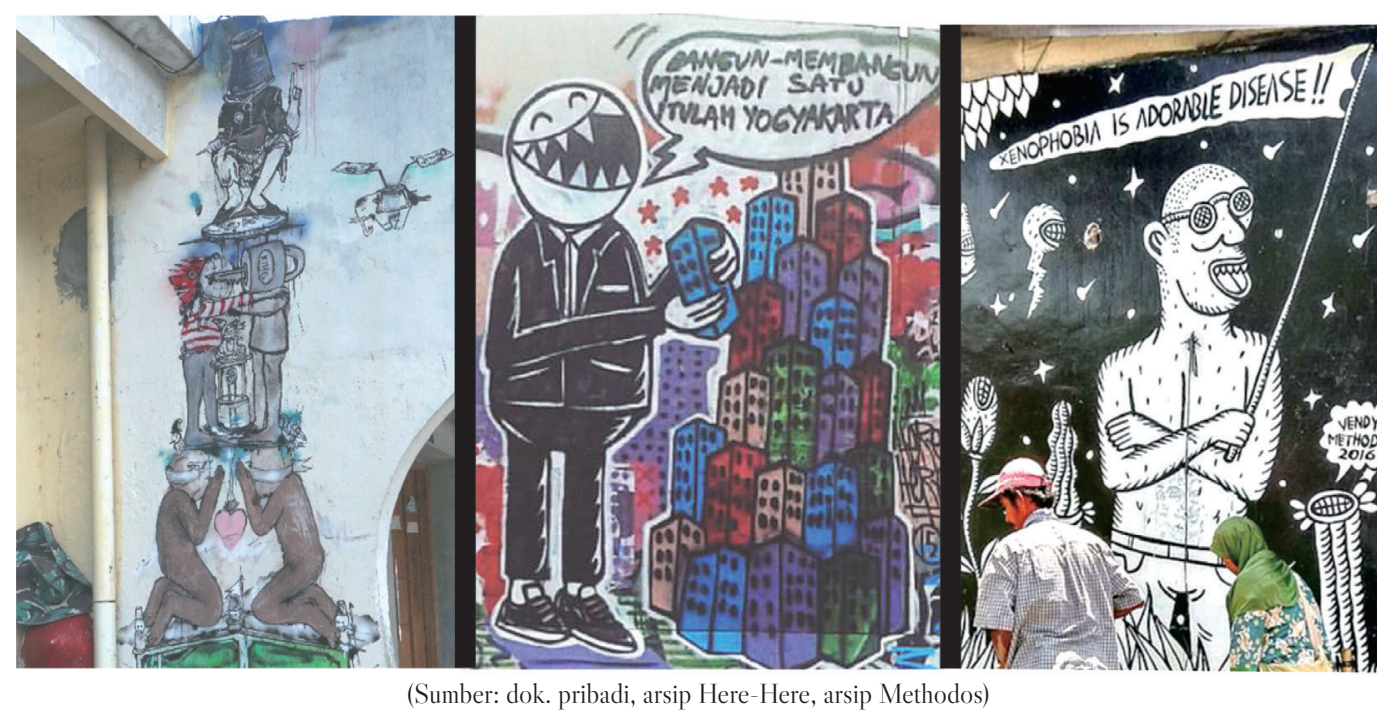

Gambar 1.

Karya Street Art Mural dari Ismu, Here-Here, Methodos (Kiri ke Kanan) 
tak melulu lucu bagi semua kalangan, dalam beberapa karya khusus karyanya bisa sangat provokatif untuk pihak-pihak tertentu.

Ketiga street art bergaya stensil di atas masing-masing dari Media-Legal, Anagard, dan Guerillas pada gambar 2 membawa isu yang berbeda. Isu yang ingin dibawa oleh Media-Legal adalah isu pertanian dimana pembangunan yang masif di Yogyakarta mengancam keberadaan ladang bercocok tanam. Stensil yang diletakkan disebuah rumah yang berjejer dengan sawah tersebut sangat sesuai dengan konteks ruangannya yang mana tembok yang dipakai menyimbolkan pembangunan itu sendiri. Apalagi karya yang dibuat pada tahun 2014 tersebut diletakkan di kawasan perbatasan kotamadya dan Kabupaten Bantul. Gambar utama dari karyanya adalah seorang petani yang mengingatkan untuk menjaga tanah agar tak hilang seperti di ibukota. Karya berikutnya dari Anagard mengomentari perilaku masyarakat modern ketika tahun 2016 banyak yang keranjingan game di gawai berjudul 'Pokemon Go'. Stensil tersebut tepat berada di pinggir jalan seolah ingin menyeberang jalan tapi malah lebih memperhatikan gawainya. Kepala manusia tersebut diubah menjadi kuda yang diken- dalikan oleh seekor karakter Pokemon di atasnya. Kemudian karya Guerillas dibuat bersamaan dengan momentum Hari Kartini tahun 2017. Stensil yang berada di Jalan Keloran perbatasan desa dan kota tersebut berada di tembok rumah pinggir jalan. Apa yang dia gambarkan adalah sosok Kartini yang melompati jendela, menyimbolkan keluar dari kurungan. Pemilihan tempat didasari Guerillas yang melihat bahwa daerah perbatasan kota-desa cocok dengan nilai-nilai perjuangan Kartini untuk menjadi perempuan mandiri. Biasanya di desa masih ada keyakinan bahwa wanita lebih baik mengurus masalah domestik di rumah saja, sedangkan di kota perempuannya sudah banyak yang bekerja.

\section{TANTANGAN YANG DIHADAPI}

Tantangan utama datang dari perebutan ruang dan risikonya muncul dari ilegalitas hukum yang mereka sandang. Perebutan ruang berarti para street artist harus bertarung dengan pelaku street art lain untuk mendapatkan tempat berkarya. Problem solving yang dicoba oleh mereka adalah dengan mengadakan project kolaboratif berkarya bersama-sama namun masih mengalami kesulitan karena perbedaan visi dimana para pelaku street art jenis

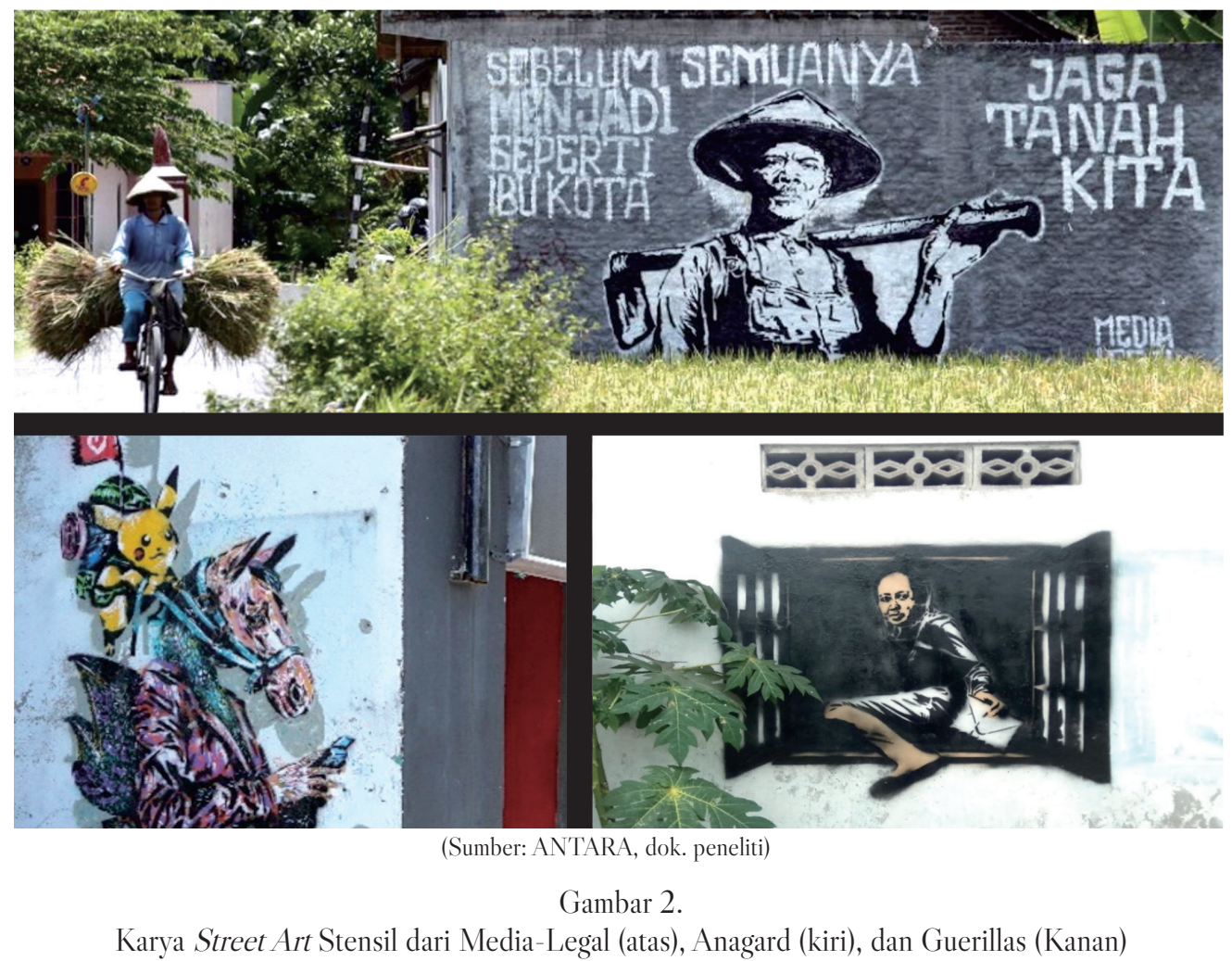


graffiti kebanyakan lebih bertumpu pada penguasaan teritori berdasarkan penyematan nama inisial di tempat-tempat strategis, sedangkan mereka yang berbasis gambar seperti mural dan stensil lebih mengutamakan pesan visual yang jelas (Bloch 2015). Anagard sempat merasa geram karena karyanya sering ditimpa oleh coret-coretan pelaku graffiti. Dirinya pun memilih untuk menjauhi ruang-ruang panas yang kerap jadi rebutan pegiat graffiti atau street art lain. Methodos menambahkan bahwa umur mural akan menjadi pendek bila memasuki spot panas. Pada akhirnya Methodos tak jarang bersama Guerillas, Media-Legal, dan Ismu mengeksplorasi tempat-tempat baru yang belum dijamah karena pada dasarnya kepekaan lingkungan sang street artist juga harus terus diasah lewat pencarian dan pembacaan ruang. Kemudian terkait ilegalitas, sejak kemunculannya street art memang akrab dengan hal ini. Mereka sering dituduh melakukan 'trespassing', atau diibaratkan oleh aparat hukum sebagai tindakan mengakses tempat yang bukan kepemilikannya untuk keperluan pribadi. Di sisi lain ruang publik sebagai milik bersama juga tak bisa diklaim kepemilikanya oleh perorangan, kebebasan publik untuk menggunakannya sebaik mungkin menjadi celah masuknya street art di sana (Young 2014:136). Street artist di Yogyakarta punya sikap sendiri dalam menghadapi bayang-bayang ilegalitas ini. Mereka bisa bergerak dalam 2 pilihan, pertama secara konvensional melakukannya dengan sembunyi-sembunyi dan kedua melakukannya dengan negoisasi terbuka sebagai wujud legalisasi. Ada kecenderungan menarik dimana dari keenam subyek, semuanya dulu mengawali turun berkarya ke jalanan secara ilegal dan sembunyi-sembunyi tanpa izin khusus. Seiring masyarakat Yogyakarta yang dirasa sudah mulai terbuka atas kehadiran karya para seniman, mereka mulai berkarya dengan cara bernegoisasi. Walau pun terkadang cara sembunyi-semunyi juga masih dilakukan pada kasus tertentu seperti saat isu yang diangkat kontroversial atau provokatif misalnya.

Tantangan lain yang tak kalah penting dalam perjalanan karier street artist adalah menjawab bagaimana caranya mereka bertahan hidup atau menafkahi diri serta keluarganya. Paling tidak ada tiga cara, yang pertama adalah lewat disewa untuk membuat karya berbayar di suatu tempat. Contohnya sekitar tahun 2015-2016 toko pusat Dagadu sebagai pusat oleh-oleh baju yang terletak di Gedongkuning menyewa jasa Media-Legal dan Anagard untuk membuat karya street art di bangunan toko. Kemudian cara yang kedua adalah membuka usaha sampingan yang berhubungan dengan street art. Cara kedua ini dilakoni oleh Here-Here yang membuka sebuah toko perlengkapan alat-alat street art dan merchandise. Toko yang berada di daerah Ngestiharjo tersebut menjual merchandise dari gambar-gamabr yang Here-Here buat seperti kaos, tas, dan sebagainya. Hal yang sama juga dilakukan Media-Legal yang menjual kaos bikinannya sendiri. Kemudian Guerillas juga bekerjasama dengan toko JokjaApparel untuk menjual gambarnya. Lalu cara yang ketiga adalah menyeimbangkan berkarya di jalanan dengan berkarya di pameran atau galeri. Apa yang patut menjadi catatan adalah seringkali bentuk pameran dan galeri street artist berbeda dari galeri yang digunakan oleh seni-seni tinggi. Bentuk galerinya biasanya kecil dan berdiri independen yang dimiliki oleh sesama seniman yang akrab dengan street art, misalnya saja Survive! Garage dan Krack! Studio \& Gallery. Bahkan yang unik pada 22 Maret 2017 ada pameran 'Voice of Wall: 6 Hours Exhibition' pada 22 Maret 2017 yang digelar Ismu, Anagard, Guerillas, bersama seniman-seniman graffiti. Pagelaran tersebut dihelat di sebuah bekas pabrik batik, tepatnya di belakang kos milik Ismu. Ruang yang tadinya mati disulap dengan respon street art menjadi galeri. Lewat galeri mandiri semacam itu karya street artist bisa laku.

PENCIP'TAAN RUANG, KRITISISME, DAN POLA PENGKARYAAN

Karier subkultural yang telah dijabarkan mulai dari latar belakang individu, pengembangan pengkaryaan, hingga tantangan yang dihadapi tadi bisa dikupas lewat teori penciptaan ruang Lefebvre. Yogyakarta tak ubahnya sebuah ruang besar yang yang di dalamnya selalu terjadi perebutan kekuasaan dan dominasi oleh pihak-pihak tertentu. Orang-orang yang berebut tadi masing-masing melakukan produksi ruang sosial. 
Suatu produksi ruang sosial dihasilkan melewati tiga konsep Triad of Social Space Production yaitu Praktik Spasial (Spatial Practices), Representasi Ruang (Representations of Space), dan Ruang Representasional (Representational Space) (Lefebvre 1991). Produksi ruang sosial dilakukan oleh para street artist karena mereka pada tahap praktik spasial terpengaruhi secara mentalitas oleh kondisi spasial yang menghasilkan nilai-nilai.

Pengaruh di tahap praktik spasial tersebut bisa datang melalui persepsi atas lingkungan, jaringan, kehidupan pribadi, waktu luang, dan pekerjaan. Selanjutnya, para aktor melihat ruang hidup yang ditinggali hanya dikuasai pihak yang berkepentingan politik dan ekonomi saja. Di sisi lain, ruang hidup yang diimajikan mereka seharusnya demokratis sehingga bisa digunakan siapa saja termasuk mereka untuk berekspresi lewat karya. Ketimpangan dua hal tersebut menghasilkan ruang 'alternatif' yang baru berupa tembok-tembok jalanan sebagai kanvas pengkaryaan street art. Lebh lanjut, terbentuk ruang berupa tembok-tembok jalanan yang sudah dipenuhi simbol-simbol berupa karya street art dengan berbagai pesan dan makna. Disini sebuah ruang dipahami secara simbolik. Simbol-simbol yang dibuat telah sukses menjadi penanda relasi antar ruang yang paling konkret. Ketika masyarakat melihat street art di tembok, mereka memaknainya sebagai simbol demokrasi atau bahkan perlawanan. Namun saat ada pelaku street art lain melihatnya bisa jadi dimaknai sebagai simbol persaingan sehingga karyanya bisa ditimpa, atau saat pemerintah melihatnya bisa jadi mereka memaknainya sebagai simbol ancaman sehingga ditangkap dengan alasan ilegal.

Sejak masing-masing dari street artist merasa ada yang salah di ruang publik, mereka mempunyai kritisisme yang sudah bisa dilihat. Saat para aktor melihat ruang hidup yang ditinggali hanya dikuasai pihak tertentu saja, dalam ruang hidup yang diimajikan mereka ingin bahwa ruang-ruang tersebut bisa digunakan siapa saja. Mereka tidak berdiam diri menerima keadaan saat ini begitu saja seperti orangorang lain, namun mereka bergerak membuat ruang ideal mereka sendiri. Hal ini sesuai konsep kritisisme yang dikatakan Agger (2008:343), kritisisme men- gantarkan mereka pada kesadaran atas dominasi yang terjadi di ruang publik. Baik secara material maupun kultural, mereka yang kritis tidak akan ikut dalam narasi besar membekukan dominasi ke dalam pola hidupnya sehari-hari. Mereka kemudian merebut kembali ruang yang mereka anggap harus demokratis lewat tembok-tembok jalanan. Kritisisme street artist juga membuat mereka sadar bahwa tembok jalanan ini bernilai paling kuat dari segi pengaruh. Jalanan merupakan elemen paling mendasar dalam membangun gambaran kota dalam benak manusia dan menjadi nadi pergerakan elemen-elemen pembentuk kota. Karenanya keberadaan jalan mutlak diperlukan bagi kemajuan sebuah kota karena menjadi akses utama setiap pihak yang berkepentingan (Lynch 1960). Jadi jika ingin menguasai kota terutama ruang publiknya, kuasai saja jalanan atau tempat-tempat yang dekat dengannya. Dari sini sudah terlihat dua sisi kritisisme street artist, yaitu dari sisi isu dan tempat. Di sisi isu mereka menyadari ada hal yang tidak beres di ruang publik. Di sisi tempat mereka menyadari harus mengambil alih dominasi lewat tembok-tembok di jalanan yang merupakan elemen mendasar sebuah kota. Kritisisme ketiga yang kemudian muncul adalah kritisisme yang terkait pada pemilihan waktu atau momentum. Pemilihan waktu terwujud dalam pengambilan keputusan kapan suatu isu harus disuarakan oleh street artist pada tempat tertentu di jalanan. Pemilihan waktu ini bisa memicu gelombang respon yang bagus dari pemirsa yang melihat mural. Contohnya adalah karya Guerillas yang membuat stensil tentang perempuan di hari kartini atau karya sindiran Anagard terhadap orang-orang yang keranjingan game yang sedang tren.

Ketiga sisi kritisisme yang dipunyai oleh street artist tak hanya sekali atau dua kali dilakukan, namun mereka melakukannya terus menerus sehingga mengkonstruksikan identitas mereka. Konstruksi identitas terbuat dari nilai dan pengetahuan dalam konteks yang ditandai dengan relasi kekuasaan (Castells 1997:7). Sebagai orang-orang yang berada dalam kondisi terstigmatisasi oleh logika dominasi dimana ruang-ruang Yogyakarta hanya dikuasai oleh pemilik kepentingan politik dan eko- 
nomi, para street artist yang memiliki nilai-nilai peduli kondisi sosial dan pengetahuan seni membangun bentuk identitas yang berupa dorongan untuk melawan. Terwujudlah resistance identity seperti yang dikatakan Castell sebagai salah satu bentuk bangunan identitas selain legitimizing identity dan project identity. Para street artist membangun resistance identity atas dasar keinginannya untuk mempertahankan ruang publik pada 'kepublikan'. Street artist juga berada pada posisi melawan dan mengkritisi berbagai masalah yang ada sekitar mereka baik itu yang datang dari pemerintah maupun dari masyarakat itu sendiri. Proses konstruksi resistance identity yang dilakukan terus menerus terimplementasi pada pola pembuatan karya street art mereka. Pola karya tersebut selanjutnya ditelusuri melalui metode following issue dan visual karya-karya Ismu, Here-Here, Methodos, Media-Legal, Anagard, dan Guerillas. Saat keenamnya diikuti pada proses pembuatan karya, ditemukan setidaknya 2 pola yang pertama bisa disebut pola issue first dan kedua place first.

Pola kerja issue first mengharuskan seniman mural untuk mencari isu terlebih dahulu untuk dijadikan sebuah bahan. Ismu mengatakan bahwa dia memilih isu yang memang dirasa paling dekat dengan dirinya di kehidupan sehari-hari. Ismu mengaku bahwa dia akan mengubah sebuah ide menjadi karya bila dia paham terlebih dahulu terhadap isu yang diangkat. Jadi isunya diolah terlebih dahulu lewat proses mencari referensi dan dasar pemikiran. Baru lah tercipta ide matang yang siap diolah menjadi visual dan kata yang menarik. "Ketika kamu ingin mengangkat isu tentang Yogyakarta kamu butuh simbol apa, lalu ketika ingin mengulik isu tentang kelaparan maka butuh unsur apa, dan seterusnya. "Nha di situ harus ada unsur yang menarik untuk bisa menarik penghuni ruang publik dan cocok dengan masyarakatnya", ujar Ismu. Setelah ada bayangan maka kemudian baru dicarikan tempat yang mendukung. Kemudian pola kerja yang kedua adalah place first, dimana seniman mural melakukan observasi tempat terlebih dahulu dan baru mendapatkan isu dari proses tersebut. Bisa dikatakan isu didapat langsung dari tempat yang telah ada setelah street artist membaca tempat dari sisi keruangannya. Pola kerja ini bisa dilihat dari project yang dibuat Ismu pada Minggiran Art Festival (MAFest) saat Maret 2017. Awalnya di bulan sebelumnya dia menemukan Kampung Minggiran sebagai lokasi yang menarik karena kampung tersebut erat dengan cerita prajurit-prajurit keraton dan bernilai budaya. Hal yang kemudian dilakukan adalah mengajak street artist lain termasuk Anagard, Media-Legal, dan Guerillas untuk bersama-sama secara kolaboratif mengangkat nilai-nilai historis ruang tersebut menjadi street art di berbagai sisi kampung. Kedua pola kerja tersebut bila digambarkan akan terlihat seperti pada Gambar 3.

Pola yang selalu diulang dan dilakukan dalam semangat resistance identity guna mempertahankan eksistensi perlawanan tersebut prakteknya tak berhenti hanya pada satu street artist. Seperti pada kasus Ismu yang membuat acara kolaboratif PreMAFest, tiap-tiap street artist juga dapat bergabung satu sama lain untuk melaksanakan pola pengkaryaan tersebut bersama-sama dalam satu payung identitas kolektif. Pada konsep konstruksi identitas Castells, ini adalah tahap lanjutan setelah individu terkonstruksikan identitasnya, masing-masing dari mereka yang merasakan kesamaan dasar akan membentuk identitas kolektif (Castells 1997:9). Bentuk identitas kolektif yang patut disebut adalah saat 2013 para street artist bersatu membuat karya tematik sampai diikuti berbagai lapisan masyarakat dalam gerakan Jogja Ora Didol. Gerakan tersebut bermula ketika 2012 saat terjadi pergantian walikota, masyarakat dari berbagai lini entah diam atau bersuara

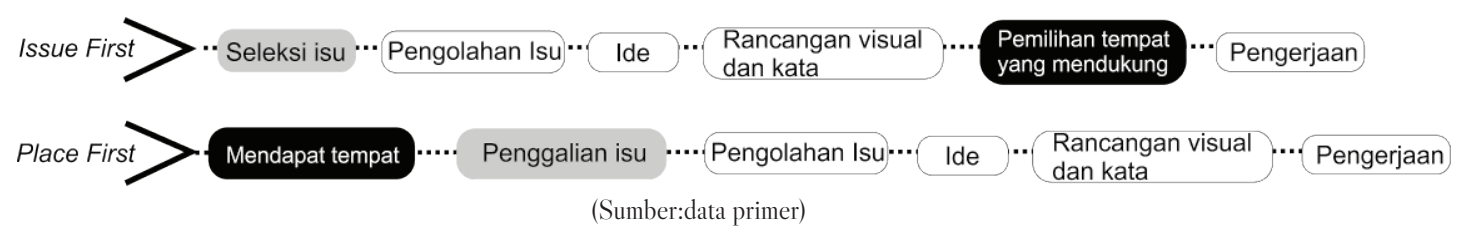

Gambar 3 .

Pola Karya Street Art 
merasa geram dengan kebijakan-kebijakan baru yang membuat kota kian sumpek dengan hotel, mall, dan billboard. Methodos, Here-Here, Ismu, dan Guerillas yang paham betul akan kondisi tersebut berdiskusi untuk membuat karya bersama. Bertepatan dengan Festival Kesenian Yogyakarta (FKY) ke-25 di tahun 2013, mereka berkolaborasi membuat karya bertema kritik pembangunan dengan media atap seng dan dipilih sebuah kata-kata tagline yang pas untuk latar gambarnya yaitu kata "Jogja Tidak Dijual”. Para street artist kemudian memindah karya di atas seng tersebut ke Kepatihan DIY saat ada acara tahunan Festival Apeman Malioboro. Kata tersebut menggema di tiap telinga masyarakat karena punya frekuensi perasaan yang sama. Pada perkembangannya kata-kata tersebut berkembang menjadi "Jogja Ora Didol". Bahasa Jawa ngoko atau kasar ini bersifat lebih menghardik, seakan-akan meminta perubahan. Karya-karya street art lain pun bermunculan dengan kata-kata yang sama. Kata tersebut juga banyak direplikasi oleh masyarakat Yogyakarta pada berbagai media sosial. Sempat juga pemerintah merasa terusik dengan kata-ata tersebut, puncaknya saat seorang pemuda bernama Muhammad Arif Buana menebalkan tulisan "Jogja Ora Didol" pada tembok bangunan di timur Pojok Beteng Wetan. Saat itu dia ditangkap Satpol PP dan terancam ditahan (Detiknews 2013).

\section{KESIMPULAN}

Street artist adalah sebuah karier yang datang dari subkultur dunia seni. Sebagai sebuah karier subkultural para street artist membawa nilai-nilai yang berbeda dibanding seniman pada umumnya. Basis utama street artist untuk berkarya bukan berada di galeri-galeri atau panggung tertutup, melainkan di ruang terbuka jalanan yang bisa diakses siapa saja. Tak jarang street artist juga erat dengan subkultur lain di daerahnya masing-masing, seperti subkultur punk misalnya. Yogyakarta sebagai kota seni dan budaya memberikan peluang untuk orangorang memiliki karier subkultural sebagai street artist. Semua pelaku street artist di Yogyakarta yang menjadi subyek penelitian memiliki persamaan dalam kesukaan terhadap seni. Sebagian besar di antaranya bahkan datang dari kalangan sekolah seni formal. Pergaulan dengan komunitas yang memiliki ketertarikan sama serta kesadaran terhadap ruang publik mengantarkan mereka menjajaki dunia street art. Sepanjang kariernya mereka mengembangkan gaya pengkaryaan dengan berbagai alat seperti wheatpaste, spray can, cetakan stensil, serta cat dan kuas sebelum pada akhirnya dominan menggunakan satu alat tertentu dan memiliki ciri khas. Tantangan mereka berkutat pada perebutan ruang, ilegalitas, dan menghidupi diri.

Jika dikupas lebih dalam, karier subkultural street artist merupakan proses panjang penciptaan ruang dan usaha-usaha untuk mempertahankannya. Para street artist terpengaruhi mentalitasnya lewat persepsi atas lingkungan, jaringan, kehidupan pribadi, waktu luang, dan pekerjaan. Kemudian kesadaran mereka terhadap kenyataan dan harapan atas ruang publik bertubrukan. Di kenyataan ruang publik Yogyakarta didominasi pihak tertentu, sedangkan harapan mereka ruang publik bisa demokratis digunakan siapapun termasuk mereka berkarya. Pada akhirnya tercipta ruang alternatif di tembok-tembok jalanan. Selanjutnya, street art di tembok tadi menjadi dimaknai simbolik oleh pemirsanya. Untuk bisa menciptakan ruang dan mempertahankannya, street artist memiliki sisi-sisi kritisisme mulai dari menyadari ada perbedaan kondisi kenyatan dan harapan di ruang publik, kemudian pemilihan jalanan sebagai elemen inti di kota, serta ketepatan dalam momentum. Sisi-sisi kritisisme dilakukan berulang kali, membangun konstruksi identitas yang berupa resistance identity. Tiap street artist berposisi melawan dan mengkritisi berbagai masalah yang ada sekitar mereka lewat dua pola pengerjaan karya, issue first atau place first. Pola tersebut juga dilakukan bersama-sama sehingga membentuk identitas kolektif. 


\section{DAFTAR PUSTAKA}

Agger, Ben. 2008. Teori Ssosial Kritis Kritik, Penerapan, dan Implikasi (Terj.). Yogyakarta: Kreasi Wacana.

Barker, Chris. 2003. Cultural Studies: Theory and Practices. London: SAGE Publications.

Bloch, Stefano. 2015. "Street Art, Public City: Law, Crime and the Urban Imagination". Urban Studies (Sage Publications, Ltd.), Vol 52, No. 13, pp. 2500-2503.

Castells, Manuel. 2010. The Power of Identity. Oxford: Blackwell Publishing Ltd.

Creswell, J. W. 2015. Research Design: Pendekatan Kualitatif, Kuantitatif, dan Mixed (Terj.). Yogyakarta: Pustaka Pelajar.

Detiknews. 2013. "Didenda Terkait Tulisan 'Jogja Ora Didol', Arif Tak Kapok Buat Mural". Detik. Diakses 21 Februari 2017 (http://news. detik.com/berita/2383521/didenda-terkaittulisan-jogja-ora-didol-arif-tak-kapok-buatmural).

Fitri, Meila Riskia. 2015. "Mural sebagai Medium Kritik Sosial Seniman (Studi Kasus "Jogja Asat")". Tesis Magister Sosiologi Universitas Gadjah Mada Yogyakarta.

Gastman, Roger, \& Caleb Neelon. 2011. The History of American Graffiti. New York: Harper Design.

Gray, Steve. 2015. "20th Century Graffiti - The Rise of Graffiti Art". Widewalls. Diakses 5 Maret 2017 (http://www.widewalls.ch/20thcentury-the-rise-of-graffiti/)

Hadi, Sutrisno. 1991. Analisa Butir untuk Instrument. Edisi pertama, Yogyakarta: Andi Offset.

Jati, Jagad Hidayat. 2015. "Kritisisme Ruang Publik: Identitas Seniman Mural di Kota Yogyakarta". Skripsi Sosiologi Universitas Gadjah Mada Yogyakarta.
John, L., Stephen, w. \& Foss K.A. 2009. Teori Komunikasi (theories of human communication) edisi 9. Jakarta: Salemba Humanika.

Lefebvre, Henri. 1991. The Production of Space. Oxford: Blackwell.

Lynch, Kevin. 1960. The Image of the City. Cambridge: MIT Press.

Schacter, Rafael. 2013. The World Atlas of Street Art and Graffiti. New Haven: Yale University Press.

Young, Alison. 2014. Street Art, Public City: Law, Grime and the Urban Imagination. New York: Routledge. 
